\title{
Impact of post biomethanated spentwash on soil properties, nutrient uptake and yield of soybean - wheat cropping sequence
}

\section{B. M. Kamble ${ }^{1^{*}}$ and A. N. Deshpande}

Agricultural Research Station, Kasabe Digraj, Sangli- 416305 (Maharashtra), INDIA

${ }^{1}$ Department of Soil Science and Agricultural Chemistry, Mahatma Phule Agricultural University, Rahuri, Ahemadnagar (Maharashtra), INDIA

*Corresponding author: E-mail: bmkamble2007@rediffmail.com

Received: July 21, 2014; Revised received: September 04, 2014; Accepted: October 27, 2014

Abstract: A field experiment was conducted on Sawargaon series of isohyperthermic family of Vertic haplustepts to study the effect of application of primary treated biomethanated spentwash (PBSW) through irrigation on soil properties, nutrient uptake and yield of soybean - wheat cropping sequence. The bulk density and hydraulic conductivity of soil were improved in $100 \%$ recommended dose (RD) of N through PBSW with and without P chemical fertilizer at soil depths of $0-15$ and $15-30 \mathrm{~cm}$. The lowest soil $\mathrm{pH}$, calcium carbonate and highest electrical conductivity, organic carbon, available $\mathrm{K}$, exchangeable sodium ( $\mathrm{Na}$ ), exchangeable sodium percentage (ESP), cation exchange capacity (CEC), sodium adsorption ratio (SAR) and pooled bacterial, fungal and actinomycetes populations in surface (0-15 $\mathrm{cm}$ ) soil depth were observed in $100 \% \mathrm{RD}$ of $\mathrm{N}$ through PBSW + with and without $\mathrm{P}$ chemical fertilizer at all three soil depths $(0-15,15-30$ and $30-60 \mathrm{~cm})$ over the other treatments. The highest pooled available soil $P$ was recorded in $50 \%$ RD of $\mathrm{N}$ through PBSW application through irrigation and remaining $\mathrm{N}$ and $\mathrm{P}$ through chemical fertilizers in all three soil depths. The significantly highest total NPK uptake by cropping sequence and highest mean Benefit : Cost $(B: C)$ ratio of soybean and wheat was recorded in $25 \%$ RD of N through PBSW + remaining N and P through chemical fertilizers over the rest of the treatments. The $25 \% \mathrm{~N}$-recommended dose of soybean and wheat crop can be replaced by application of PBSW through irrigation in sequence without disturbing soils by salt load.

Keywords: Economics, Effluent, Soybean-wheat sequence, Soil properties

\section{INTRODUCTION}

Fertilizers play an important role in increasing productivity and production. An estimated contribution of fertilizers as an input is $50-60 \%$. However, the cost of fertilizers is increasing day by day, so that there is urgent need for utilization of available alternative resources, viz., farm yard manure (FYM), compost, green manure, recycled crop residues and agricultural industrial wastes, e.g., spentwash, which is the cheapest source of nutrients for plant through the application in appropriate quantity without affecting soil health (Joshi et al., 1994).

India is the largest sugarcane producer in the world and a large number of sugar factories produce substantial amounts of molasses. Molasses serves as raw material for production of alcohol. The liquid left after distillation, known as spentwash, vinasse, etc., can be utilized in agriculture as liquid manure. The quantity of spentwash produced in distillery is about 12 to 15 times more than that of alcohol produced (Manohar Rao, 1983). The spentwash produced in this process is called raw spentwash and when it is treated with bacteria for methanation the remaining liquid is called primary biomethanated spentwash (PBSW). If the distillery effluent is used after proper dilution, crops show good response to distillery effluent application (Joshi et al.,1994; Zalawadia and Raman 1994). Soybean-wheat cropping system has emerged as an important cropping system only after 1980 with the introduction of soybean as a kharif crop in wheat -growing areas of the country particularly under irrigated system. Different doses of raw spentwash have been tried in combination with different types of fertilizers in agricultural fields and there are reports of both positive and negative impacts. In this context, the present investigation was undertaken for the use of PBSW as liquid manure particularly for soybean- wheat cropping sequence in command area. Because of high biological oxygen demand (BOD), chemical oxygen demand (COD), high salt content, acidic $\mathrm{pH}$ of raw spentwash can affect the plant growth, but PBSW having low BOD, COD and comparatively low salt content and neutral $\mathrm{pH}$ can be tolerated by plant and judicious use can provide a cheapest nutrient source to the plants. However, continuous long term uses of PBSW can also detoriate the soil health. It should be monitored by taking research trials with the following objectives: i) to study the effect of PBSW application through irrigation on physical, chemical and biological proper- 
ties of soil and ii) to study the effect of PBSW application through irrigation on nutrient uptake and yield of soybean and wheat cropping sequence.

\section{MATERIALS AND METHODS}

The field experiment was conducted during 2009-10 and 2010-11 for research study on fixed site of Sawargaon series of isohyperthermic family of Vertic haplustepts; however, the field experiment was initiated during 2007-08 at Post Graduate Research Farm, Mahatma Phule Krishi Vidyapeeth, Rahuri, Maharashtra, India. The initial experimental soil belonging to was alkaline ( $\mathrm{pH} 8.40$ ), having EC 0.40 $\mathrm{dS} \mathrm{m}{ }^{-1}$, calcareous $\left(\mathrm{CaCO}_{3} 15.80 \%\right)$, clayey in texture with bulk density of $1.42 \mathrm{Mg} \mathrm{m}^{-3}$, hydraulic conductivity $0.37 \mathrm{~cm} \mathrm{hr}^{-1}$, mean weight diameter $0.14 \mathrm{~mm}$, exchangeable $\mathrm{Na}^{+}\left(0.71 \mathrm{cmol}\left(\mathrm{p}^{+}\right) \quad \mathrm{kg}^{-1}\right)$ and exchangeable sodium percentage (1.44). The soil had available $\mathrm{N}$ (alkaline $\left.\mathrm{KMnO}_{4}\right) 190 \mathrm{~kg} \mathrm{ha}^{-1}, \mathrm{P}$ (Olsen P) $8.50 \mathrm{~kg} \mathrm{ha}^{-1}$ and $\mathrm{K}\left(\mathrm{NH}_{4} \mathrm{OAc}\right) 582 \mathrm{~kg} \mathrm{ha}^{-1}$ and saturation paste extract of soil having $\mathrm{pHs}-8.12$ ECe-0.88 dS m $\mathrm{m}^{-1}, \mathrm{Na}^{+}$was $9.5 \mathrm{meq} \mathrm{L}^{-1}$.The experiment was laid out in randomized complete blocks design with five treatments, viz., recommended dose (RD)-NPK $\left(\mathrm{T}_{1}\right), 100 \% \mathrm{RD}$ of $\mathrm{N}$ through PBSW without $\mathrm{P}$ chemical fertilizer $\left(\mathrm{T}_{2}\right), 100 \% \mathrm{RD}$ of $\mathrm{N}$ through $\mathrm{PBSW}+$ remaining $\mathrm{P}$ through chemical fertilizer $\left(\mathrm{T}_{3}\right), 50 \% \mathrm{RD}$ of $\mathrm{N}$ through PBSW + remaining $\mathrm{N}$ and $\mathrm{P}$ through chemical fertilizers $\left(\mathrm{T}_{4}\right)$ and $25 \% \mathrm{RD}$ of $\mathrm{N}$ through PBSW + remaining $\mathrm{N}$ and $\mathrm{P}$ through chemical fertilizers $\left(\mathrm{T}_{5}\right)$ and replicated in four times. The crop spacing was $30 \mathrm{~cm} \mathrm{X} 10 \mathrm{~cm}$ (row X plant) for soybean and $22.5 \mathrm{~cm}$ (row) for wheat. The basal recommended dose of fertilizer (RDF) was applied for soybean (50:75 N: $\left.\mathrm{P}_{2} \mathrm{O}_{5} \mathrm{~kg} \mathrm{ha}^{-1}\right)$ as per the treatments. The RDF for wheat was 120:60:40 ( $\left.\mathrm{N}: \mathrm{P}_{2} 0_{5}: \mathrm{K}_{2} 0 \mathrm{~kg} \mathrm{ha}^{-1}\right)$, out of which half dose of $\mathrm{N}\left(60 \mathrm{~kg} \mathrm{ha}^{-1}\right)$ and full dose of $60 \mathrm{~kg} \mathrm{P}_{2} \mathrm{O}_{5}$ ha $^{-1}$ and $40 \mathrm{~kg} \mathrm{~K}_{2} \mathrm{O} \mathrm{ha}^{-1}$ in treatment $\mathrm{T}_{1}$ as basal dose and remaining $1 / 2$ dose of $\mathrm{N}$ was applied after 21 days of sowing. In treatment $\mathrm{T}_{2}, \mathrm{~T}_{3}-100 \%, \mathrm{~T}_{4}$ $-50 \%$ and in $\mathrm{T}_{5} 25 \% \mathrm{~N}$ dose was applied through PBSW. In $\mathrm{T}_{5} 25 \%$ dose of $\mathrm{N}$ at sowing was supported through chemical fertilizer. The PBSW was applied at $2^{\text {nd }}$ and $3^{\text {rd }}$ irrigation in two equal splits for soybean during 2009-10. The application of PBSW through irrigation was not possible due to continuous rains in the year 2010-11. The application of PBSW in three equal splits for wheat at $3^{\text {rd }}, 4^{\text {th }}$ and $5^{\text {th }}$ irrigation during the year 2009-10 and 2010-11 was done as per treatments (Tables 1 and 2). All cultural practices including gap filling, thinning, weeding, plant protection measures and other cultural practices were done in both the crops as per the recommendations of Mahatma Phule Agricultural University. The total rainfall during the crop growth period of soybean was $441 \mathrm{~mm}$ (26 rainy days) and $798 \mathrm{~mm}$ (28 rainy days) and for wheat it was $148 \mathrm{~mm}$ (9 rainy days) and 103 $\mathrm{mm}$ (6 rainy days) during the year 2009-10 and 2010-
11, respectively. The irrigation water used for irrigating soybean and wheat had low salinity and sodicity. The PBSW was obtained from the distillery of Shri. Baburaoji Tanpure co-operative sugar factory, Rahuri, district Ahmednagar of Maharashtra State which had mean characters viz., $\mathrm{pH} 7.48$, EC $36.48 \mathrm{dS} \mathrm{m} \mathrm{m}^{-1}$, BOD 5443 and COD $24874 \mathrm{mg} \mathrm{L}^{-1}, \mathrm{~K}^{+} 0.98 \%, \mathrm{Ca}^{2+}, \mathrm{Mg}^{2+}$, $\mathrm{Na}^{+}, \mathrm{SO}_{4}{ }^{2-}$ and $\mathrm{Cl}^{-}$were $3422,2923,2391,2643$ and $2215 \mathrm{mg} \mathrm{L}^{-1}$, respectively.

Soil, plant sampling and analysis: The initial soil samples were collected at $0-15,15-30$ and $30-60 \mathrm{~cm}$ depths from each plot at the time of wheat harvest of $2^{\text {nd }}$ year and further soil samples were done at the time of soybean and wheat harvest in the $3^{\text {rd }}$ and $4^{\text {th }}$ year (2009-10 and 2010-11). These samples were analyzed for physical (two depths:0-15 and 15-30 cm), chemical parameters (three depths:0-15, 15-30 and 30-60 cm) and microbial count (one depth:0-15 cm). The soil samples were dried in shade ground and sieved through $0.5 \mathrm{~mm}$ sieve for organic carbon and $2 \mathrm{~mm}$ sieve for general analysis. Soil samples were analysed for bulk density by core sampler method (Blake and Hartage,1986), hydraulic conductivity by constant head method (Klute and Dirksen, 1986). The soil pH and electrical conductivity were measured 1:2.5 soil suspension (Jackson, 1973). The organic carbon content of soil was determined by Walkley and Black method (Nelson and Sommers, 1982). The calcium carbonate $\left(\mathrm{CaCO}_{3}\right)$ content of soil was determined by rapid titration method (Allison and Moodier,1965). The exchangeable $\mathrm{Na}^{+}$was estimated by flame photometer (Richard 1954). The cation exchange capacity (CEC) of soil was estimated by saturating solution of ammonium acetate + ammonium chloride and extracting solution of magnesium nitrate (Palemio and Rhoades, 1977). The exchangeable sodium percentage (ESP) was calculated as exchangeable $\mathrm{Na}^{+}$ divided by CEC multiplied by 100 (Richards 1954). The soil samples were analysed for available $\mathrm{N}$ by alkaline permanganate method (Subbiah and Asija, 1956), available $\mathrm{P}$ (Olsen- $\mathrm{P}$ ) by $0.5 \mathrm{M} \mathrm{NaHCO}$ extraction (Olsen et al.,1954), available $\mathrm{K}\left(\mathrm{NH}_{4} \mathrm{OAc}\right)$ by $1 \mathrm{~N}$ neutral $\mathrm{NH}_{4} \mathrm{OAc}$ extraction on flame photometer (Knudsen et al.,1982). The microbial populations were estimated by serial dilution plate technique (Halvorson and Zieglar,1993). The saturated paste extracts of soil were prepared and analyzed for $\mathrm{pH}, \mathrm{EC}$, major cations viz. $\mathrm{Na}^{+}, \mathrm{K}^{+}, \mathrm{Mg}^{2+}, \mathrm{Ca}^{2+}$ and major anions viz; $\mathrm{HCO}_{3}{ }^{2-}$, $\mathrm{Cl}^{-}$and $\mathrm{SO}_{4}{ }^{2-}$ (Richards, 1954).

The plant and grain samples were collected at the time of harvest and analyzed for total $\mathrm{N}$ by micro-Kjeldahl method in $\mathrm{H}_{2} \mathrm{SO}_{4}: \mathrm{H}_{2} \mathrm{O}_{2}(1: 1)$ digestion (Parkinson and Allen, 1975), total $\mathrm{P}$ by vanadomolybdate yellow colour method in nitric acid $\mathrm{H}_{2} \mathrm{SO}_{4}: \mathrm{HClO}_{4}: \mathrm{HNO}_{3}$ (1:4:10) digestion (Jackson, 1973) and total $\mathrm{K}$ on flame photometer in $\mathrm{H}_{2} \mathrm{SO}_{4}: \mathrm{HClO}_{4}: \mathrm{HNO}_{3} \quad(1: 4: 10)$ (Chapman and Pratt, 1961). The statistical analysis was carried out by procedure suggested by Panse and 
Sukhatme (1985).

\section{RESULTS AND DISCUSSION}

Effect of PBSW irrigation on physical properties Bulk density: The highest pooled bulk density of soil was recorded in RD-NPK $\left(\mathrm{T}_{1}\right)$ in surface depth and subsurface soil depths. The lowest pooled mean bulk density of soil was noticed in $\mathrm{T}_{2}$ and $\mathrm{T}_{3}$ treatments as compare to RD-NPK as well as in both the years and both the soil depths (Table 3). The bulk density of soil was slightly reduced at wheat harvest 2010-11 as compare to initial values. The addition of colloidal organic matter through PBSW which is also readily oxidizable increased the pore space in soil and improved the physical properties. Hati et al. (2004) reported that the application of post-methanation effluent (PME) showed a significant improvement in the physical properties of soil. The mean weight diameter, per cent water-stable aggregation, saturated hydraulic conductivity and water retention at 0.033 $\mathrm{MPa}$ suction were significantly $(\mathrm{P}<0.05)$ more while bulk density and penetration resistance was significantly less in PME-treated plots than that of control. Deshpande et al. (2012) reported that the physical properties [bulk density, mean weight diameter (MWD) of water-stable aggregates and hydraulic conductivity] of soil were improved in both layers of sodic soil $(0-30$ and $30-60 \mathrm{~cm})$ as a result of the addition of increased doses of PBSW.

Hydraulic conductivity: The highest pooled hydraulic conductivity of soil was observed in treatment $T_{3}$ in surface depth $\left(0.455 \mathrm{~cm} \mathrm{hr}^{-1}\right)$ and $\mathrm{T}_{2}$ in sub-surface depth $\left(0.419 \mathrm{~cm} \mathrm{hr}^{-1}\right)$ as compared to rest of other treatments. The significantly lowest hydraulic conductivity of soil $\left(0.383\right.$ and $\left.0.362 \mathrm{~cm} \mathrm{hr}^{-1}\right)$ was found in RD-NPK over the rest of other treatments in 0 -15 and $15-30 \mathrm{~cm}$ soil depths. The highest pooled hydraulic conductivity of soil was observed in surface depth as compared to subsurface depth. The highest hydraulic conductivity of soil was gradually increased at the end of experiment as compared to initial values (Table 3). The hydraulic conductivity of soil was increased due to the higher amount of colloidal organic matter present in the PBSW which resulted in aggregation of soil particles and thereby decrease in bulk density and increase in the pore space, aeration which improves the structure of soil (Hati et al., 2004 and Deshpande et al., 2012).

Effect of PBSW irrigation on chemical properties Soil pH (1:2.5): The highest pooled soil $\mathrm{pH}$ (8.18, 8.14 and 8.12) was observed in treatment $T_{1}$ at all the soil depths. The highest decrease in soil $\mathrm{pH}$ was found in surface depth $0-15 \mathrm{~cm}$ as compare to below both the depths (15-30 and 30-60 cm). Among the PBSW application through irrigation treatments, the lowest $\mathrm{pH}$ (7.81, 7.84 and 7.91) was observed in treatment $\mathrm{T}_{2}$ and highest was noticed in $\mathrm{T}_{5}(8.01,7.98$ and 8.03) at all the soil depths (Table 4). As the dose of PBSW increased there was decrease in $\mathrm{pH}$ in all three soil depths in both the years of experimentation and pooled mean. This might be due to high amount of application of PBSW, which contains high colloidal organic matter which releases organic acids (R-COOH) after decomposition that can reduce soil $\mathrm{pH}$ due to $\mathrm{H}^{+}$ dissociation from carboxyl groups. The increase in spentwash application resulted in a notable decrease in the $\mathrm{pH}$ of soils (Saliha, 2003).

Electrical conductivity: The EC of all three soil depths was increased in all PBSW treatments as compared to without application of PBSW (RD-NPK) in both the years of study and in pooled mean. The highest pooled EC of soil $\left(1.34,1.51\right.$ and $\left.1.65 \mathrm{dS} \mathrm{m}^{-1}\right)$ was recorded in treatment $\mathrm{T}_{2}(100 \% \mathrm{~N}-\mathrm{PBSW}+$ without $\mathrm{P}$ chemical fertilizer) and it was at par with $\mathrm{T}_{3}\left(1.18,1.31\right.$ and $\left.1.54 \mathrm{dS} \mathrm{m}^{-1}\right)$ in all the three soil depths. The lowest pooled EC of soil $(0.57,0.53$ and $0.62 \mathrm{dS} \mathrm{m}^{-1}$ ) was noticed in treatment $\mathrm{T}_{1}$ (RD-NPK) and it was at par with treatment $\mathrm{T}_{5}(25 \% \mathrm{~N}-\mathrm{PBSW}+$ remaining $\mathrm{N}$ and $\mathrm{P}$-chemical fertilizers) at 0-15 (0.75 $\left.\mathrm{dS} \mathrm{m} \mathrm{m}^{-1}\right)$ and $15-30 \mathrm{~cm}\left(0.88 \mathrm{dS} \mathrm{m}^{-1}\right)$ soil depths. The PBSW application through irrigation was increased EC of soil in all the treatments at the end of experiment as compare to initial values (Table 4). As there was increased PBSW increased soluble salt concentrations in soil. The increase in EC of soil due to increase in PBSW doses might be due to the fact that PBSW contains higher amounts of soluble salts (34.90$38.06 \mathrm{dS} \mathrm{m}^{-1}$ ). Saliha (2003) reported that the EC of soil increased markedly due to accumulation of salts from spentwash.

Organic carbon: The highest pooled organic carbon content in soil $(0.62$ and $0.52 \%)$ was recorded in $\left(\mathrm{T}_{2}\right)$ $100 \% \mathrm{~N}-\mathrm{PBSW}+$ without P chemical fertilizer at 0-15 and $15-30 \mathrm{~cm}$ soil depths and it was at par with treatments $\mathrm{T}_{1}(0.60$ and $0.54 \%)$ and $\mathrm{T}_{3}(0.57$ and 0.51 $\%$ ) at $0-15$ and $15-30 \mathrm{~cm}$ soil depths (Table 5). The lowest pooled organic carbon content in the soil $(0.51$ and $0.42 \%$ ) was noticed in treatment $\mathrm{T}_{5}$. The increase in soil organic carbon with increased levels of PBSW application might be cause of large quantities of colloidal organic matter added through PBSW. The order of organic carbon in different soil depths was 0-15 $>15-30>30-60 \mathrm{~cm}$ soil depth. This might be due to surface application of PBSW which enriches the surface soil layer with organic carbon and then this process was further extended to lower depths. In the treatments of 100 $\% \mathrm{~N}-\mathrm{PBSW}+$ with and without $\mathrm{P}$ chemical fertilizer there was build up of organic carbon throughout the soil profile as compare to other treatments tested (Table 5). This was happen because the distillery effluent had a high concentration of colloidal forms of organic matter and its application led to increased organic carbon in post harvest soil. Deshpande et al., (2012) stated that the significant increase in organic carbon was observed in both soil layers as a result of the addition of PBSW at $180 \mathrm{~m}^{3} \mathrm{ha}^{-1}$. 
Table 1. Nutrients applied through PBSW and chemical fertilizers to soybean.

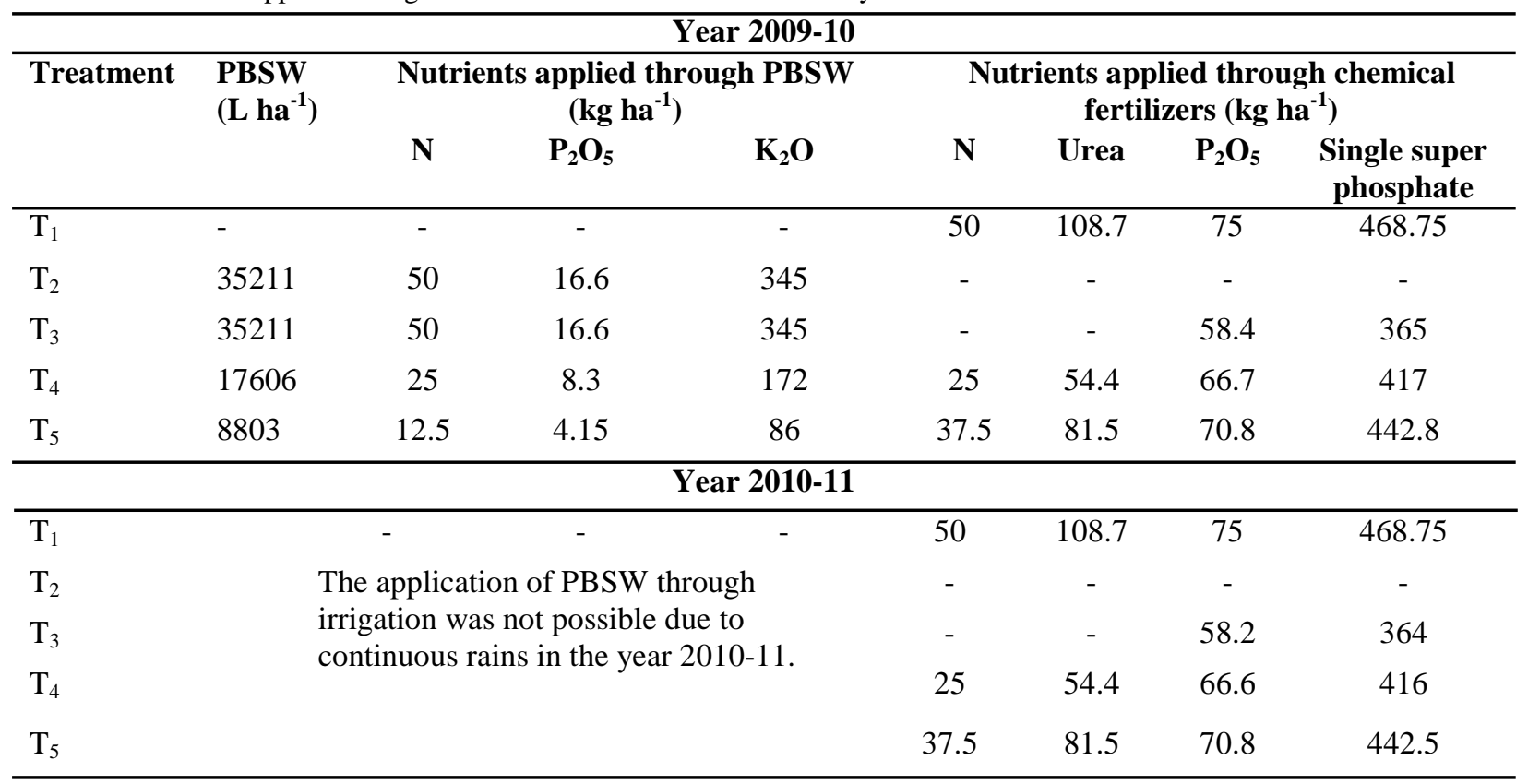

Table 2 . Nutrients applied through PBSW and chemical fertilizers to wheat.

\begin{tabular}{|c|c|c|c|c|c|c|c|c|c|c|}
\hline \multicolumn{11}{|c|}{ Year 2009-10 } \\
\hline \multirow[t]{2}{*}{ Treatment } & \multirow[t]{2}{*}{$\begin{array}{l}\text { PBSW } \\
\left(\mathrm{L} \mathrm{ha}^{-1}\right)\end{array}$} & \multicolumn{3}{|c|}{$\begin{array}{l}\text { Nutrients applied } \\
\text { through PBSW }\left(\mathrm{kg} \mathrm{ha}^{-1}\right)\end{array}$} & \multicolumn{6}{|c|}{$\begin{array}{l}\text { Nutrients applied through chemical fertilizers } \\
\qquad\left(\mathrm{kg} \mathrm{ha}^{-1}\right)\end{array}$} \\
\hline & & $\mathbf{N}$ & $\mathbf{P}_{2} \mathbf{O}_{5}$ & $\mathrm{~K}_{2} \mathrm{O}$ & $\mathbf{N}$ & Urea & $\mathbf{P}_{2} \mathbf{O}_{5}$ & $\begin{array}{c}\text { Single super } \\
\text { phosphate }\end{array}$ & $\mathrm{K}_{2} \mathrm{O}$ & $\begin{array}{c}\text { Potassium } \\
\text { chloride }\end{array}$ \\
\hline $\mathrm{T}_{1}$ & - & - & - & - & 120 & 260 & 60 & 375 & 40 & 67 \\
\hline $\mathrm{T}_{2}$ & 85714 & 120 & 45 & 849 & - & - & - & - & - & - \\
\hline $\mathrm{T}_{3}$ & 85714 & 120 & 45 & 849 & - & - & 15 & 93 & - & - \\
\hline $\mathrm{T}_{4}$ & 42857 & 60 & 22.5 & 424 & 60 & 130 & 37.5 & 234 & - & - \\
\hline $\mathrm{T}_{5}$ & 21428.5 & 30 & 11.3 & 212 & 90 & 195.6 & 48.7 & 304.5 & - & - \\
\hline \multicolumn{11}{|c|}{ Year 2010-11 } \\
\hline $\mathrm{T}_{1}$ & - & - & - & - & 120 & 260 & 60 & 375 & 40 & 67 \\
\hline $\mathrm{T}_{2}$ & 86331 & 120 & 52 & 854 & - & - & - & - & - & - \\
\hline $\mathrm{T}_{3}$ & 86331 & 120 & 52 & 854 & - & - & 8 & 50 & - & - \\
\hline $\mathrm{T}_{4}$ & 43165 & 60 & 26 & 427 & 60 & 130 & 34 & 212 & - & - \\
\hline $\mathrm{T}_{5}$ & 21583 & 30 & 13 & 213 & 90 & 195.6 & 47 & 294 & - & - \\
\hline
\end{tabular}

Calcium carbonate: The lowest pooled $\mathrm{CaCO}_{3}$ content in soil (15.46, 15.68 and $15.79 \%)$ was recorded in treatment $\mathrm{T}_{2}$ at all the soil depths. The treatments $\mathrm{T}_{2}(15.46 \%)$ and $\mathrm{T}_{3}(15.56 \%)$ were at par with each other for pooled $\mathrm{CaCO}_{3}$ content at $0-15 \mathrm{~cm}$ soil depth. The more amount of pooled $\mathrm{CaCO}_{3}$ content in soil was present in $15-30 \mathrm{~cm}$ subsurface soil depth as compare to $0-15$ and $30-60 \mathrm{~cm}$ soil depths. The highest pooled $\mathrm{CaCO}_{3}$ content in soil was noticed in RD-NPK (16.70 and $17.09 \%$ ) at 0-15 and 15-30 cm soil depths as compare to rest of the treatments (Table 5). It clearly indicated that as the quantity of PBSW applied through irrigation was increased it helped to decrease the $\mathrm{CaCO}_{3}$ content of 0-15 and $15-30 \mathrm{~cm}$ soil depths. The continuous PBSW application through irrigation decreased the $\mathrm{CaCO}_{3}$ content of all the three soil depths studied at the end of the experiment (wheat harvest 2010-11) over the initial soil values due to PBSW application through irrigation may be the result of decrease in soil $\mathrm{pH}$ and production of organic acids as a result of decomposition of organic matter, which had lead to the solubilization of $\mathrm{CaCO}_{3}$ and thereafter it's leaching below the root zone. This might be due to more leaching of $\mathrm{CaCO}_{3}$ due to heavy rainfall, 
Table 3. Effect of PBSW application through irrigation on bulk density and hydraulic conductivity of soil at harvest of soybean and wheat.

\begin{tabular}{|c|c|c|c|c|c|c|c|c|c|}
\hline \multirow[t]{2}{*}{ Treatment } & \multirow{2}{*}{$\begin{array}{c}\text { Soil } \\
\text { depth } \\
\text { (cm) }\end{array}$} & \multicolumn{3}{|c|}{ Bulk density $\left(\mathrm{Mg} \mathrm{m}^{-3)}\right.$} & \multirow[t]{2}{*}{$\begin{array}{c}\text { Pooled } \\
\text { mean }\end{array}$} & \multicolumn{3}{|c|}{$\begin{array}{c}\text { Hydraulic conductivity } \\
\left(\mathrm{cm} \mathrm{hr}^{-1}\right)\end{array}$} & \multirow[t]{2}{*}{$\begin{array}{c}\text { Pooled } \\
\text { mean }\end{array}$} \\
\hline & & Initial & $\begin{array}{l}\text { Soybean } \\
2009-10 \\
\end{array}$ & $\begin{array}{l}\text { Wheat } \\
\text { 2010-11 }\end{array}$ & & Initial & $\begin{array}{r}\text { Soybean } \\
2009-10 \\
\end{array}$ & $\begin{array}{l}\text { Wheat } \\
\text { 2010-11 }\end{array}$ & \\
\hline \multirow[t]{2}{*}{$\mathrm{T}_{1}$} & $0-15$ & 1.40 & $1.41^{\mathrm{a}}$ & $1.43^{\mathrm{a}}$ & $1.42^{\mathrm{a}}$ & 0.378 & $0.381^{b}$ & $0.386^{\mathrm{b}}$ & $0.383^{\mathrm{d}}$ \\
\hline & $15-30$ & 1.45 & $1.46^{\mathrm{a}}$ & $1.47^{\mathrm{a}}$ & $1.46^{\mathrm{a}}$ & 0.354 & $0.359^{\mathrm{b}}$ & $0.365^{\mathrm{b}}$ & $0.362^{\mathrm{d}}$ \\
\hline \multirow[t]{2}{*}{$\mathrm{T}_{2}$} & $0-15$ & 1.38 & $1.37^{\mathrm{c}}$ & $1.35^{\mathrm{b}}$ & $1.36^{\mathrm{c}}$ & 0.445 & $0.450^{\mathrm{a}}$ & $0.458^{\mathrm{a}}$ & $0.454^{\mathrm{a}}$ \\
\hline & $15-30$ & 1.42 & $1.42^{\mathrm{b}}$ & $1.40^{\mathrm{c}}$ & $1.41^{\mathrm{c}}$ & 0.412 & $0.417^{\mathrm{a}}$ & $0.421^{\mathrm{a}}$ & $0.419^{\mathrm{a}}$ \\
\hline \multirow[t]{2}{*}{$\mathrm{T}_{3}$} & $0-15$ & 1.37 & $1.37^{\mathrm{c}}$ & $1.35^{\mathrm{b}}$ & $1.36^{\mathrm{c}}$ & 0.444 & $0.452^{\mathrm{a}}$ & $0.458^{\mathrm{a}}$ & $0.455^{\mathrm{a}}$ \\
\hline & $15-30$ & 1.42 & $1.42^{\mathrm{b}}$ & $1.40^{\mathrm{c}}$ & $1.41^{\mathrm{c}}$ & 0.409 & $0.414^{\mathrm{a}}$ & $0.419^{\mathrm{a}}$ & $0.417^{\mathrm{b}}$ \\
\hline \multirow[t]{2}{*}{$\mathrm{T}_{4}$} & $0-15$ & 1.39 & $1.39^{\mathrm{b}}$ & $1.36^{\mathrm{b}}$ & $1.38^{\mathrm{b}}$ & 0.440 & $0.443^{\mathrm{a}}$ & $0.445^{\mathrm{a}}$ & $0.444^{\mathrm{b}}$ \\
\hline & $15-30$ & 1.44 & $1.43^{\mathrm{b}}$ & $1.42^{\mathrm{b}}$ & $1.43^{\mathrm{b}}$ & 0.385 & $0.388^{\mathrm{a}}$ & $0.390^{\mathrm{ab}}$ & $0.389^{c}$ \\
\hline \multirow[t]{2}{*}{$\mathrm{T}_{5}$} & $0-15$ & 1.40 & $1.40^{\mathrm{ab}}$ & $1.38^{\mathrm{b}}$ & $1.39^{\mathrm{b}}$ & 0.426 & $0.433^{\mathrm{a}}$ & $0.438^{\mathrm{a}}$ & $0.436^{\mathrm{c}}$ \\
\hline & $15-30$ & 1.45 & $1.45^{\mathrm{a}}$ & $1.44^{\mathrm{b}}$ & $1.44^{\mathrm{b}}$ & 0.384 & $0.386^{\mathrm{a}}$ & $0.389^{a b}$ & $0.388^{\mathrm{c}}$ \\
\hline \multirow[t]{2}{*}{ S.E. \pm} & $0-15$ & 0.005 & 0.005 & 0.010 & 0.006 & 0.008 & 0.009 & 0.008 & 0.0006 \\
\hline & $15-30$ & 0.004 & 0.005 & 0.009 & 0.003 & 0.009 & 0.011 & 0.011 & 0.0005 \\
\hline \multirow[t]{2}{*}{$\mathrm{CD}(0.05)$} & $0-15$ & 0.015 & 0.016 & 0.032 & 0.019 & 0.026 & 0.027 & 0.026 & 0.0019 \\
\hline & $15-30$ & 0.013 & 0.015 & 0.026 & 0.010 & 0.027 & 0.035 & 0.035 & 0.0015 \\
\hline
\end{tabular}

irrigation and high quantity of PBSW application. The significant reduction in calcium carbonate was observed in 0-30 and 30-60 cm soil layers as a result of the addition of PBSW at $180 \mathrm{~m}^{3} \mathrm{ha}^{-1}$ (Deshpande et al., 2012).

Cation exchange capacity: The highest pooled CEC of soil $\left\{\left(53.83,48.55\right.\right.$ and $\left.\left.47.60 \mathrm{cmol}\left(\mathrm{p}^{+}\right) \mathrm{kg}^{-1}\right)\right\}$ was observed in treatment $\mathrm{T}_{3}$ at all the soil depths. The treatment $\mathrm{T}_{3}$ was at par with treatments $\mathrm{T}_{2}\{(53.40$, 48.16 and $\left.\left.47.21 \mathrm{cmol}^{+}\left(\mathrm{p}^{+}\right) \mathrm{kg}^{-1}\right)\right\}$ and $\mathrm{T}_{4}\{(52.87,47.69$ and $\left.\left.46.75 \mathrm{cmol}\left(\mathrm{p}^{+}\right) \mathrm{kg}^{-1}\right)\right\}$ at all three soil depths. Significantly lowest pooled CEC was noticed in all three soil depths studied in $\mathrm{T}_{1}$ (RD-NPK). Similar trend of CEC at all the three soil depths was noticed at soybean and wheat harvest 2010-11. The CEC of soil was increased at the end of experiment (wheat harvest 2010-11) as compare to initial values at all the soil depths (Table 6). The highest CEC of soil was noticed in surface depth $(0-15 \mathrm{~cm})$ and decreased with increasing depth of soil in pooled means as well as in all the four seasons. As the PBSW application through irrigation quantity was increased the CEC of soil was also increased. This might be due to high amount of cations as well as organic matter in PBSW (Deshpande et al., 2012).

Exchangeable $\mathrm{Na}^{+}$: The highest pooled exchangeable $\mathrm{Na}^{+}$was observed in treatment $\mathrm{T}_{2}\left\{\left(2.36 \mathrm{cmol}\left(\mathrm{p}^{+}\right) \mathrm{kg}^{-1}\right)\right\}$ at $0-15 \mathrm{~cm}$ soil depth and treatment $\mathrm{T}_{3}\{(2.75$ and 2.72 $\left.\left.\mathrm{cmol}\left(\mathrm{p}^{+}\right) \mathrm{kg}^{-1}\right)\right\}$ at $15-30$ and $30-60 \mathrm{~cm}$ soil depths over the rest of other treatments. Among the PBSW treatments, the lowest pooled exchangeable $\mathrm{Na}^{+}$was found in treatment $\mathrm{T}_{5}\left\{\left(1.86,1.79\right.\right.$ and $1.64 \mathrm{cmol}\left(\mathrm{p}^{+}\right)$ $\left.\left.\mathrm{kg}^{-1}\right)\right\}$ followed by treatment $\mathrm{T}_{4}\{(2.07,2.17$ and 2.05 cmol $\left.\left.\left(\mathrm{p}^{+}\right) \mathrm{kg}^{-1}\right)\right\}$. The exchangeable $\mathrm{Na}^{+}$was gradually increased in all the soil depths in PBSW treatments at the end of experiment (wheat harvest 2010-11) as compare to initial soil values and this increase was more substantial in treatments $\mathrm{T}_{2}$ and $\mathrm{T}_{3}$. The exchangeable $\mathrm{Na}^{+}$was gradually increased due to continuous application of PBSW with high salt load, which increased salt concentration in clayey soils, increased conductivity and there by saturation of salts in lower soil depths (Table 6). In due course of time this saturated soil depths with salts particularly with $\mathrm{Na}^{+}$were responsible for increasing exchangeable $\mathrm{Na}^{+}$. The presown application of PBSW @ 50,000 L ha ${ }^{-1}$ increased exchangeable $\mathrm{Na}^{+}$ of soil was $0.11 \mathrm{cmol}(\mathrm{p}+) \mathrm{kg}^{-1}$ (5.47 to $5.58 \mathrm{cmol}(\mathrm{p}+)$ $\mathrm{kg}^{-1}$ ) at harvest of pearl millet (Deshpande et al., 2009).

Exchangeable sodium percentage: The higher pooled ESP of soil was recorded in $100 \% \mathrm{~N}-\mathrm{PBSW}+$ without $\mathrm{P}$ chemical fertilizer at all the soil depths. The increased ESP of soil due to the increasing levels of PBSW, which contain high amount of salt load particularly sodium was responsible for increased exchangeable sodium as well as ESP (Table 7). Among the PBSW treatments, the lowest ESP of soil was noticed in $25 \% \mathrm{~N}$-PBSW + remaining $\mathrm{N}$ and P-chemical fertilizers as compare to $\mathrm{T}_{3}$ and $\mathrm{T}_{2}$ in all the seasons of experiment and pooled means. Increased levels of PBSW application fertigation increased ESP of soil. Kayalvizhi et al. (2001) reported the increase in ESP due to repeated application of distillery effluent and it was maintained below 15. The ESP of soil was gradually increased at the end of experiment as compare to initial values. The greater ESP of soil was observed in wheat harvest 2010-11 i.e. at the end of experiment as compare to soybean harvest 2009-10. This was due to continuous application of PBSW to 
B. M. Kamble and A. N. Deshpande / J. Appl. \& Nat. Sci. 6 (2): $552-569$ (2014)

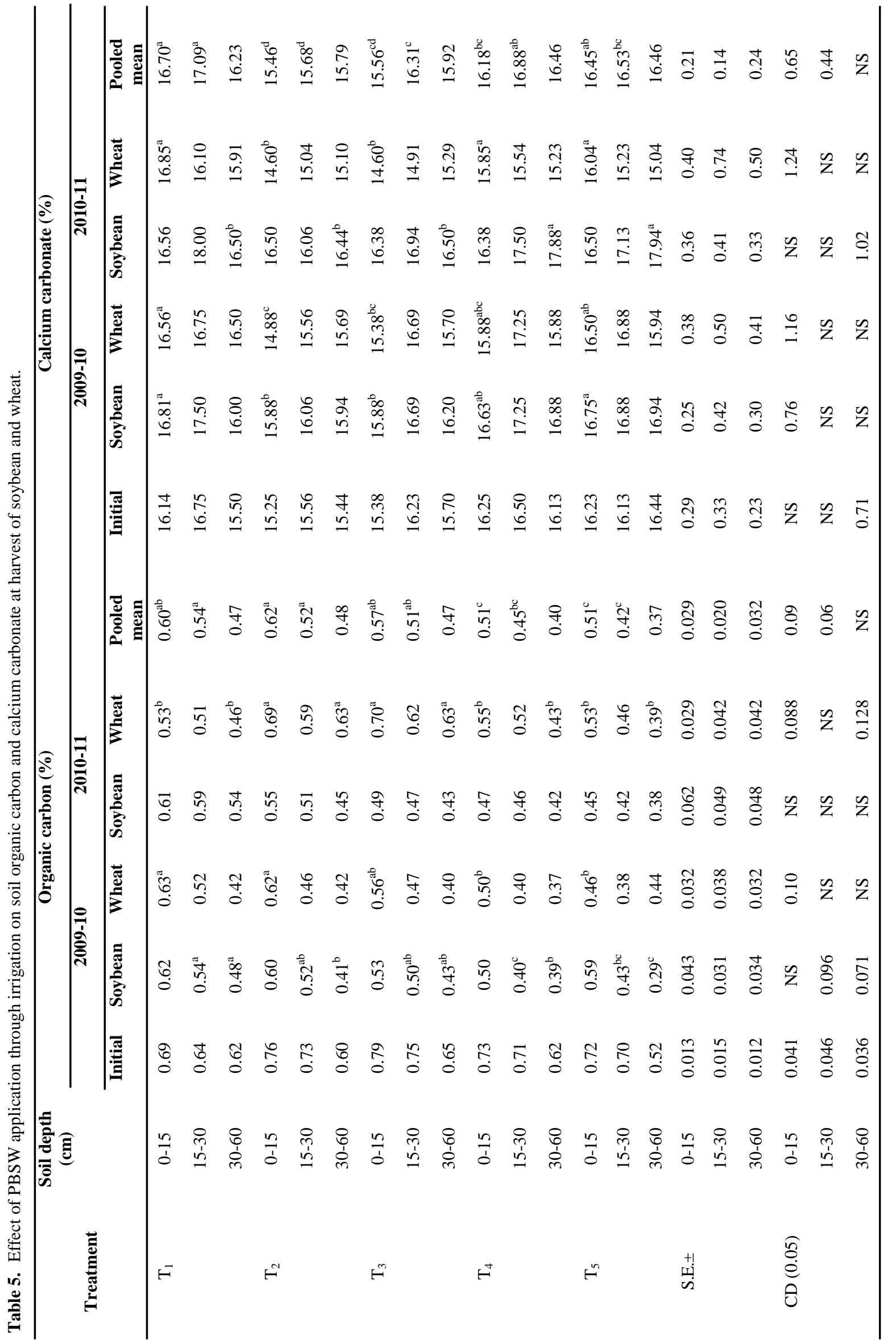


soybean and wheat crop, which was responsible in increasing exchangeable $\mathrm{Na}^{+}$and ultimately ESP of soil.

Effect of PBSW irrigation on soil available nutrients Available nitrogen: The highest pooled available $\mathrm{N}$ was recorded in treatment $\mathrm{T}_{5}\left(188\right.$ and $\left.177 \mathrm{~kg} \mathrm{ha}^{-1}\right)$ and it was at par with treatment $\mathrm{T}_{4}(50 \% \mathrm{~N}$ PBSW + remaining $\mathrm{N}$ and $\mathrm{P}$ - chemical fertilizers) and $\mathrm{T}_{1}$ in $0-15$ and $15-30 \mathrm{~cm}$ soil depths. Among the PBSW application treatments, the lowest pooled available $\mathrm{N}$ was recorded in the treatments $\mathrm{T}_{2}$ (173 and $156 \mathrm{~kg} \mathrm{ha}^{-1}$ ) and $\mathrm{T}_{3}\left(171\right.$ and $\left.160 \mathrm{~kg} \mathrm{ha}^{-1}\right)$ and these were at par with each other at 0-15 and 15-30 cm soil depths (Table 7). The highest available nitrogen content in soil was observed in surface depth than subsurface depths. In general, the available $\mathrm{N}$ was steadily increased in all three soil depths and in all the treatments from $1^{\text {st }}$ sampling to last sampling. The building of soil available $\mathrm{N}$ in all treatments was due to legume-cereal crop rotation. As the quantity of PBSW was increased, the available $\mathrm{N}$ content in soil was decreased in all the three soil depths. This might be due to high COD and BOD of PBSW which resulted in immobilization of available $\mathrm{N}$. The high COD and BOD can increase the temperature and immobilize the nutrients particularly $\mathrm{N}$ as well as depletion of oxygen in soil (Kalaiselvi and Mahimairaja, 2010).

Available phosphorus: The highest pooled available $\mathrm{P}$ content in soil $\left(16.21,15.11\right.$ and $\left.12.18 \mathrm{~kg} \mathrm{ha}^{-1}\right)$ was recorded in treatment $\mathrm{T}_{4}(50 \% \quad \mathrm{~N}-\mathrm{PBSW}$ and remaining $\mathrm{N}$ and $\mathrm{P}$-chemical fertilizers) at all the soil depths. The increase in available $\mathrm{P}$ with PBSW application through irrigation might be due to mineralization and solubilization of native $\mathrm{P}$ as well as applied $\mathrm{P}$ through the chemical fertilizer. The treatment $\mathrm{T}_{4}$ was at par with treatment $\mathrm{T}_{5}(15.07,13.85$ and $\left.11.62 \mathrm{~kg} \mathrm{ha}^{-1}\right)$ at all the soil depths and treatment $\mathrm{T}_{1}\left(13.86\right.$ and $\left.10.05 \mathrm{~kg} \mathrm{ha}^{-1}\right)$ at $0-15 \mathrm{~cm}$ and $30-60 \mathrm{~cm}$ soil depths. The highest availability of pooled $\mathrm{P}$ was observed in surface 0-15 cm soil depth than 15-30 and 30-60 cm soil depths in all the treatments (Table 8). The lowest available $P$ was found in $T_{2}$ over the rest of other treatments during both the years of study. The increase in available $\mathrm{P}$ with fertigation of $25-50 \% \mathrm{~N}$ through PBSW might be due to fast mineralization of PBSW and solubilization of native $\mathrm{P}$ as well as applied $\mathrm{P}$ through the chemical fertilizer due to release and formation of weak acid during the course of mineralization of organic matter. The available phosphorus status was significantly improved at 120 $\mathrm{m}^{3} \mathrm{ha}^{-1}$ level of post biomethanated spentwash + RDF treatment (Deshpande et al., 2011).

Available potassium: The highest pooled available $\mathrm{K}$ content in soil $\left(749,713\right.$ and $\left.580 \mathrm{~kg} \mathrm{ha}^{-1}\right)$ was recorded in treatment $\mathrm{T}_{2}$ at all the soil depths. The treatment $\mathrm{T}_{2}$ was at par with treatments $\mathrm{T}_{3}$ (731 and $693 \mathrm{~kg} \mathrm{ha}^{-1}$ ) and $\mathrm{T}_{4}\left(715\right.$ and $\left.616 \mathrm{~kg} \mathrm{ha}^{-1}\right)$ at $0-15$ and $15-30 \mathrm{~cm}$ soil depths and $\mathrm{T}_{3}\left(563 \mathrm{~kg} \mathrm{ha}^{-1}\right)$ at $30-60 \mathrm{~cm}$ soil depth. The lowest available $\mathrm{K}$ content in soil $(555,472$ and $405 \mathrm{~kg}$ $\mathrm{ha}^{-1}$ ) was noticed in the treatment where no application of PBSW was done i.e. RD-NPK in both the years of experimentation (Table 8). As the dose of PBSW increased there was increase in pooled soil available $\mathrm{K}$ in all the three soil depths tested. The high soil available $\mathrm{K}$ in PBSW treatments was due to the presence of high in PBSW. In addition, the high organic matter content of PBSW and its decomposition resulting in release of organic acids which might have solubilised $\mathrm{K}$ bearing minerals contributing to $\mathrm{K}$ availability. Bhosale et al. (2009) reported that the application of PBSW $40 \mathrm{~m}^{3} \mathrm{ha}^{-1}$ maintained higher $\mathrm{K}$ fertility of soil as compared to lower levels of PBSW application and control, by maintaining higher levels of water soluble $\mathrm{K}$, exchangeable $\mathrm{K}$, non exchangeable $\mathrm{K}$ and lattice $\mathrm{K}$ after harvest. Higher levels of PBSW enhanced the step $\mathrm{K}$ and constant $\mathrm{K}$ realize as well as $\mathrm{K}$ fixing capacity of soil as compare to lower levels of PBSW and control, indicating build up of $\mathrm{K}$ fertility of soil.

Effect of PBSW irrigation on saturation paste extract of soil $\mathrm{pH}$ of saturation paste extract (pHs): The lowest pooled $\mathrm{pHs}$ of soil was observed in treatment $\mathrm{T}_{2}(7.64,7.63$ and 7.67$)$ at all the soil depths as compared to other treatments. The highest pooled $\mathrm{pHs}$ of soil was noticed in treatment $\mathrm{T}_{1}(7.95,7.95$ and 7.90) at all the soil depths as compared to rest of other treatments (Table 9). There was no drastic change in soil pHs at the end of experimentation as compare to initial values in PBSW applied treatments. The increased rate of application of PBSW proportionately decreased pHs of soil at all the soil depths as well as in pooled means in both the years of study. The reduction in the $\mathrm{pH}$ of saturation paste extract was also observed due to application of distillery effluent (Deshpande $e t$ al., 2011).

Electrical conductivity of saturation paste extract $\left(\mathbf{E C}_{\mathrm{e}}\right)$ : The significantly lowest pooled $\mathrm{EC}_{\mathrm{e}}$ of soil was found in treatment $\mathrm{T}_{1}\left(1.16,1.39\right.$ and $\left.1.10 \mathrm{dS} \mathrm{m}^{-1}\right)$ over the rest of other treatments at all the soil depths. The highest pooled ECe of soil was recorded in treatment $\mathrm{T}_{2}$ $\left(3.15,3.56\right.$ and $\left.3.74 \mathrm{dS} \mathrm{m}^{-1}\right)$ at all the soil depths. $\mathrm{H} \quad \mathrm{O} \quad \mathrm{w} \quad \mathrm{e} \quad \mathrm{v} \quad \mathrm{e} \quad \mathrm{r}$, treatments $T_{2}$ and $T_{3}$ were at par with each other at all the three soil depths tested (Table 9). The minimum salt accumulation was observed in RD-NPK followed by $25 \% \mathrm{~N}-\mathrm{PBSW}+$ remaining $\mathrm{N}$ and $\mathrm{P}$ - chemical fertilizers during 2009-10, 2010-11 and pooled means. The gradual increase in salt concentration was found in all the PBSW treatments at all the soil depths as compare to initial soil values. This was directly related to the quantity of PBSW applied as it contains high amount of soluble salts. The EC of soil increased

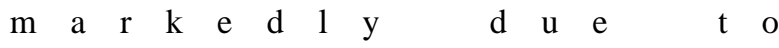
accumulation of salts from spentwash (Saliha, 2003).

Sodium adsorption ratio (SAR): The significantly highest pooled SAR values of soil extract was recorded 


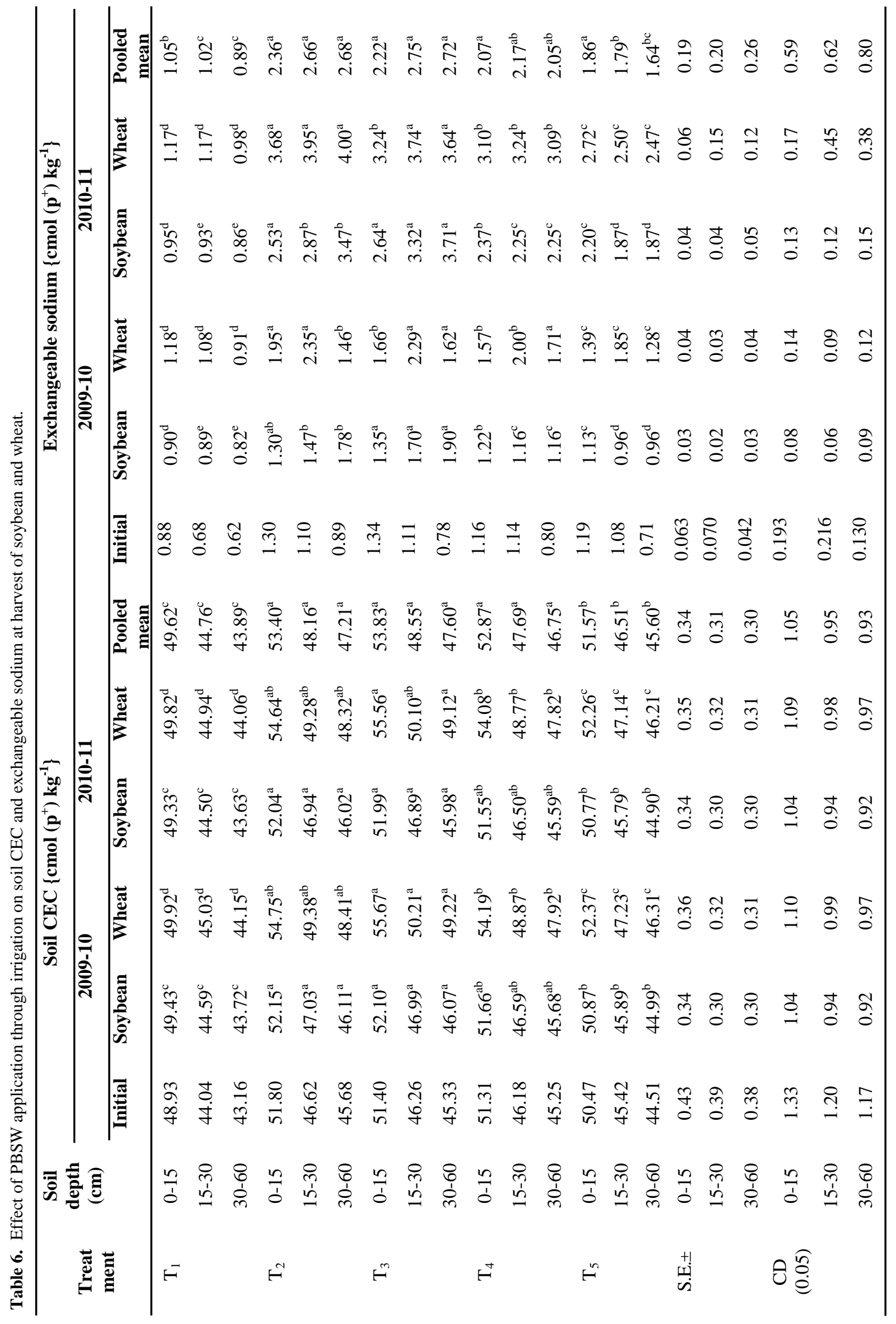


B. M. Kamble and A. N. Deshpande / J. Appl. \& Nat. Sci. 6 (2): $552-569$ (2014)

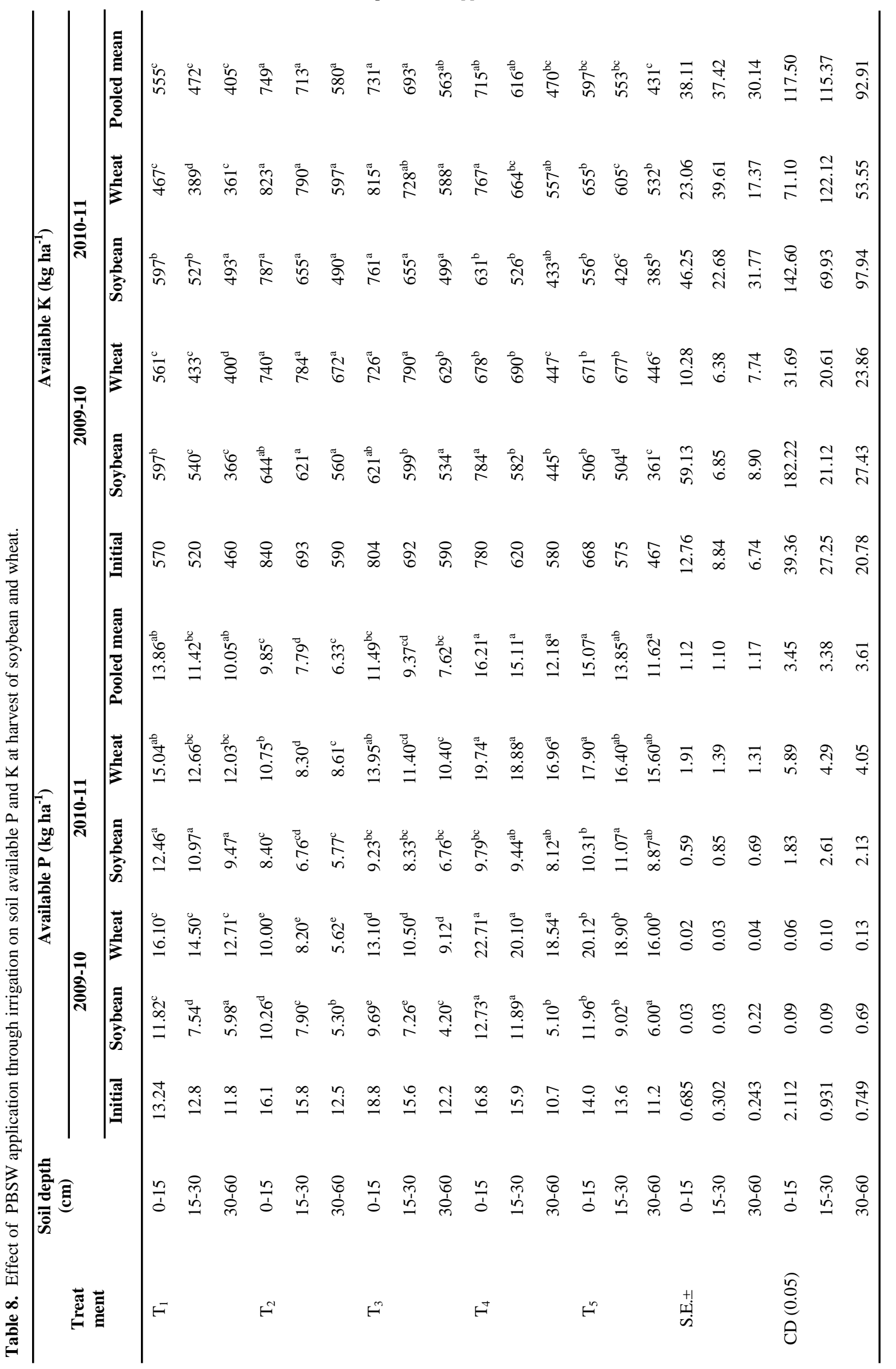


Table 10. Effect of PBSW application through irrigation on SAR in saturation paste extract of soil at harvest of soybean and wheat.

\begin{tabular}{|c|c|c|c|c|c|c|c|}
\hline \multirow{3}{*}{ Treatment } & \multirow{3}{*}{$\begin{array}{l}\text { Soil depth } \\
\text { (cm) }\end{array}$} & & \multicolumn{4}{|c|}{ SAR $\left(\mathrm{m} \mathrm{mol} \mathrm{L}^{-1}\right)^{1 / 2}$} & \multirow[t]{3}{*}{ Pooled mean } \\
\hline & & \multirow[b]{2}{*}{ Initial } & \multicolumn{2}{|c|}{$2009-10$} & \multicolumn{2}{|c|}{ 2010-11 } & \\
\hline & & & Soybean & Wheat & Soybean & Wheat & \\
\hline \multirow[t]{3}{*}{$\mathrm{T}_{1}$} & $0-15$ & 1.21 & $1.27^{\mathrm{c}}$ & $1.37^{\mathrm{c}}$ & $0.98^{\mathrm{bc}}$ & 1.40 & $1.25^{\mathrm{b}}$ \\
\hline & $15-30$ & 0.88 & $0.90^{\mathrm{b}}$ & 1.63 & $1.35^{\mathrm{b}}$ & $1.43^{\mathrm{c}}$ & $1.33^{\mathrm{c}}$ \\
\hline & $30-60$ & 1.02 & $1.02^{\mathrm{c}}$ & 1.55 & $1.49^{\mathrm{c}}$ & $1.50^{\mathrm{d}}$ & $1.39^{\mathrm{c}}$ \\
\hline \multirow[t]{3}{*}{$\mathrm{T}_{2}$} & $0-15$ & 2.62 & $2.78^{\mathrm{a}}$ & $1.84^{\mathrm{a}}$ & $1.74^{\mathrm{a}}$ & 1.77 & $2.03^{\mathrm{a}}$ \\
\hline & $15-30$ & 2.34 & $2.24^{\mathrm{a}}$ & 1.74 & $2.05^{\mathrm{a}}$ & $2.72^{\mathrm{a}}$ & $2.19^{\mathrm{a}}$ \\
\hline & $30-60$ & 1.50 & $1.54^{\mathrm{ab}}$ & 1.62 & $2.67^{\mathrm{a}}$ & $3.10^{\mathrm{a}}$ & $2.23^{\mathrm{a}}$ \\
\hline \multirow[t]{3}{*}{$\mathrm{T}_{3}$} & $0-15$ & 2.72 & $2.82^{\mathrm{a}}$ & $1.71^{\mathrm{ab}}$ & $1.71^{\mathrm{a}}$ & 1.73 & $1.99^{\mathrm{a}}$ \\
\hline & $15-30$ & 2.26 & $2.25^{\mathrm{a}}$ & 1.60 & $1.93^{\mathrm{a}}$ & $2.33^{\mathrm{ab}}$ & $2.03^{\mathrm{a}}$ \\
\hline & $30-60$ & 1.60 & $1.62^{\mathrm{a}}$ & 1.53 & $2.62^{\mathrm{a}}$ & $2.80^{\mathrm{a}}$ & $2.14^{\mathrm{ab}}$ \\
\hline \multirow[t]{3}{*}{$\mathrm{T}_{4}$} & $0-15$ & 2.04 & $2.11^{\mathrm{b}}$ & $1.42^{\mathrm{c}}$ & $1.25^{\mathrm{b}}$ & 1.38 & $1.54^{\mathrm{b}}$ \\
\hline & $15-30$ & 1.92 & $1.88^{\mathrm{a}}$ & 1.68 & $1.35^{\mathrm{b}}$ & $2.16^{\mathrm{ab}}$ & $1.77^{\mathrm{ab}}$ \\
\hline & $30-60$ & 1.09 & $1.07^{\mathrm{bc}}$ & 1.50 & $2.06^{\mathrm{b}}$ & $2.26^{\mathrm{ab}}$ & $1.72^{\mathrm{bc}}$ \\
\hline \multirow[t]{3}{*}{$\mathrm{T}_{5}$} & $0-15$ & 1.90 & $1.95^{\mathrm{b}}$ & $1.45^{\mathrm{bc}}$ & $0.93^{\mathrm{c}}$ & 1.32 & $1.41^{\mathrm{b}}$ \\
\hline & $15-30$ & 1.26 & $1.23^{\mathrm{b}}$ & 1.58 & $1.27^{\mathrm{b}}$ & $1.82^{\mathrm{bc}}$ & $1.48^{\mathrm{bc}}$ \\
\hline & $30-60$ & 1.04 & $1.02^{\mathrm{c}}$ & 1.54 & $2.00^{\mathrm{b}}$ & $2.12^{\mathrm{ab}}$ & $1.67^{\mathrm{c}}$ \\
\hline \multirow[t]{3}{*}{ S.E. \pm} & $0-15$ & 0.11 & 0.13 & 0.09 & 0.09 & 0.16 & 0.12 \\
\hline & $15-30$ & 0.15 & 0.15 & 0.08 & 0.13 & 0.19 & 0.14 \\
\hline & $30-60$ & 0.15 & 0.16 & 0.08 & 0.12 & 0.41 & 0.14 \\
\hline \multirow[t]{3}{*}{$\mathrm{CD}(0.05)$} & $0-15$ & 0.34 & 0.39 & 0.28 & 0.28 & NS & 0.36 \\
\hline & $15-30$ & 0.46 & 0.46 & NS & 0.39 & 0.59 & 0.43 \\
\hline & $30-60$ & 0.48 & 0.49 & NS & 0.36 & 1.25 & 0.42 \\
\hline
\end{tabular}

in treatment $\mathrm{T}_{2}(2.03,2.19$ and 2.23$)$ at all the soil depths over the rest of other treatments and it was at par with treatments $T_{3}(1.99,2.03$ and 2.14) at all the soil depths and $\mathrm{T}_{4}(1.77)$ at $15-30 \mathrm{~cm}$ soil depth. The lowest pooled SAR values of soil extract was observed in treatment $\mathrm{T}_{1}(1.25,1.33$ and 1.39) over the rest of other treatments at all the soil depths and it was at par with treatments $\mathrm{T}_{5}(1.41,1.48$ and 1.67$)$ at all the soil depths and with $\mathrm{T}_{4}(1.54$ and 1.72$)$ at $0-15$ and $30-60$ $\mathrm{cm}$ soil depths (Table 10). It was clearly indicated that the increase in PBSW application through irrigation increased SAR values of soil extract. The increase in SAR values as increase in quantity PBSW application through irrigation was due to higher soluble $\mathrm{Na}^{+}$ concentration present in PBSW in both the years of study and SAR values of soil extract in all the three soil depths were gradually increased at the end of experiment as compare to initial soil values. The PBSW also contain high amount of colloidal organic matter which decomposes easily and thereby increase physical properties of surface soil, due to which there was leaching of $\mathrm{Na}^{+}$from surface layer to 15-30 and $30-60 \mathrm{~cm}$ soil layer. This leaching of $\mathrm{Na}^{+}$in lower layers was responsible for increasing SAR of lower layers. In the case of vertisol and alfisol, Murugaragavan (2002) observed increase in SAR and ESP due to application of spentwash. However, these values (SAR <3.62; ESP <4.8) were well below the threshold levels, suggesting even at higher rate the spentwash application is unlikely to cause any sodicity problem in these soils.

Effect of PBSW irrigation on microbial properties of soil: The higher bacterial, fungal and actinomycetes population were observed in treatment $\mathrm{T}_{3}$ and followed by treatment $T_{2}$ in pooled mean and two years of the experimentation. This might be due to the high organic carbon content in PBSW also helped in increasing bacterial population as well as different levels of PBSW (Table 11). Mallika et al., (2003) reported that the microbial population increased upto flowering stage and thereafter it decreased. The high organic carbon content of PBSW serves as food and energy for soil microorganisms. The microbial populations (bacteria,fungi, actinomycetes, azotobacter, and phosphate-solubilizing bacteria) increased withan increase in the levels of application of PBSW (Deshpande et al., 2012). However, the lowest bacterial, fungal and actinomycetes population was 
Table 11. Effect of PBSW application through irrigation on microbial population at harvest of soybean and wheat $(0-15 \mathrm{~cm}$ soil depth).

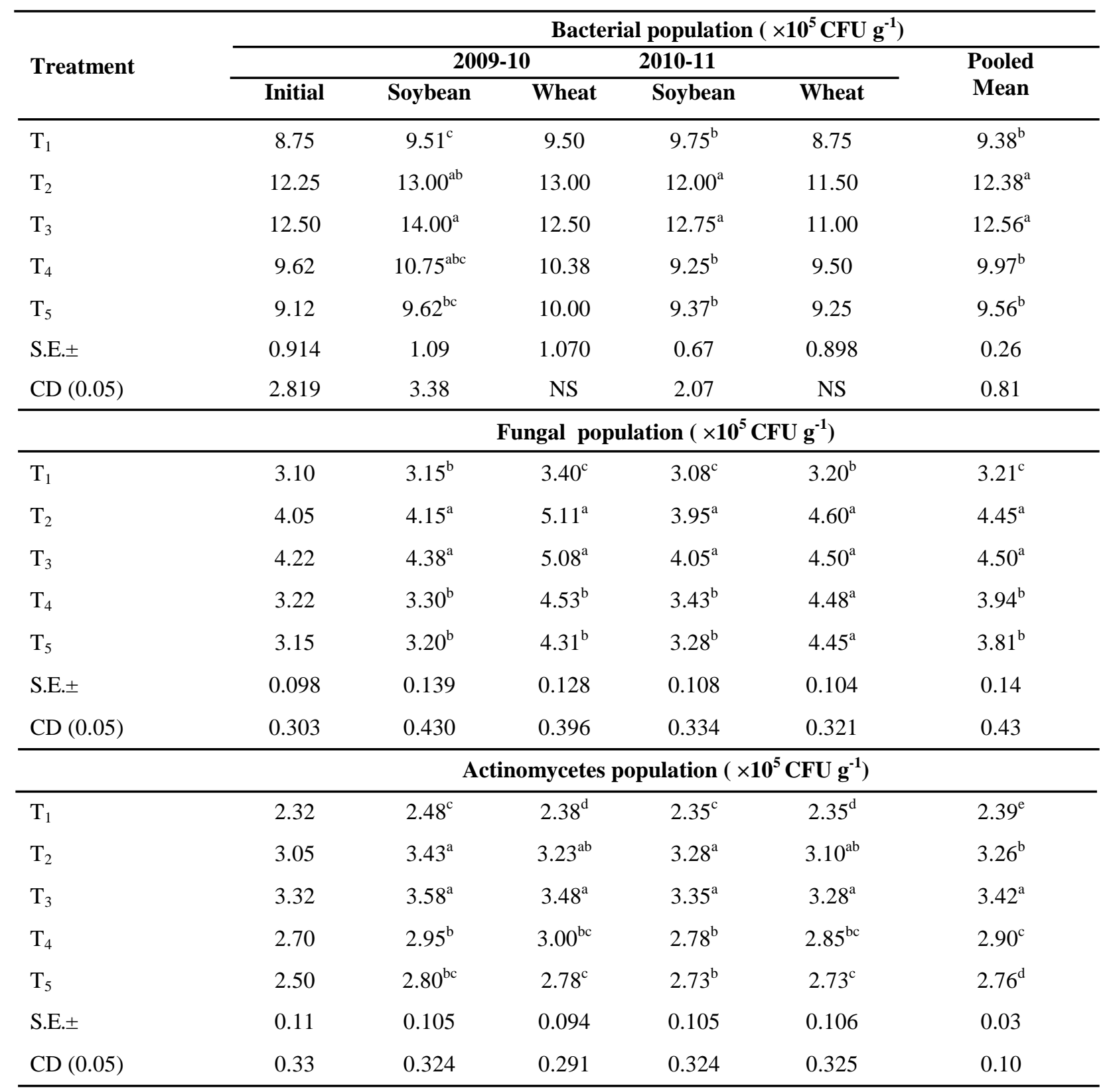

observed in RD-NPK in both the years of experimentation.

Effect of PBSW irrigation on uptake of NPK: The highest total uptake of $\mathrm{N}$ and $\mathrm{P}$ by cropping sequence was noticed in $25 \% \mathrm{RD}$ of $\mathrm{N}$ - PBSW + remaining $\mathrm{N}$ and $\mathrm{P}$ through chemical fertilizers (Table 12 ) and total uptake of K in RD-NPK over the rest of other treatments (Table 12). The treatments RD-NPK and $25 \% \mathrm{RD}$ of $\mathrm{N}-\mathrm{PBSW}+$ remaining $\mathrm{N}$ and $\mathrm{P}$ through chemical fertilizers were at par with each other for total uptake of N, P and K by cropping sequence. Inc r e a s e P B S W a p l i c a t i o n proportionately, decreased the total $\mathrm{N}, \mathrm{P}$ and $\mathrm{K}$ uptake by soybean and wheat crop during both the years of experimentation (Table 12). The increased total uptake of $\mathrm{N} \mathrm{P}$ and $\mathrm{K}$ by soybean and wheat was found in 25 and $50 \% \mathrm{~N}-\mathrm{PBSW}+$ remaining $\mathrm{N}$ and P-chemical fertilizers. This might be due to more solubility of chemical fertilizers as well as fast mineralization of PBSW applied in small quantity which increased the availability of nutrients, ultimately increased yield and uptake of nutrients. Sukanya and Meli (2004) indicated that the total nutrient uptake by wheat was significantly higher at 1:50 dilution level as it produced maximum biomass and economic yield.

\section{Effect of PBSW irrigation on Yield}

Grain and straw yield of soybean: The treatment $T_{1}$ (3.83 $\mathrm{q} \mathrm{ha}^{-1}$ ) recorded highest grain yield of soybean and it was at par with $\mathrm{T}_{5}\left(3.44 \mathrm{q} \mathrm{ha}^{-1}\right)$. Whereas, the treatment $\mathrm{T}_{5}(25 \% \mathrm{~N}-\mathrm{PBSW}+$ remaining $\mathrm{N}$ and $\mathrm{P}$ 
B. M. Kamble and A. N. Deshpande / J. Appl. \& Nat. Sci. 6 (2): $552-569$ (2014)

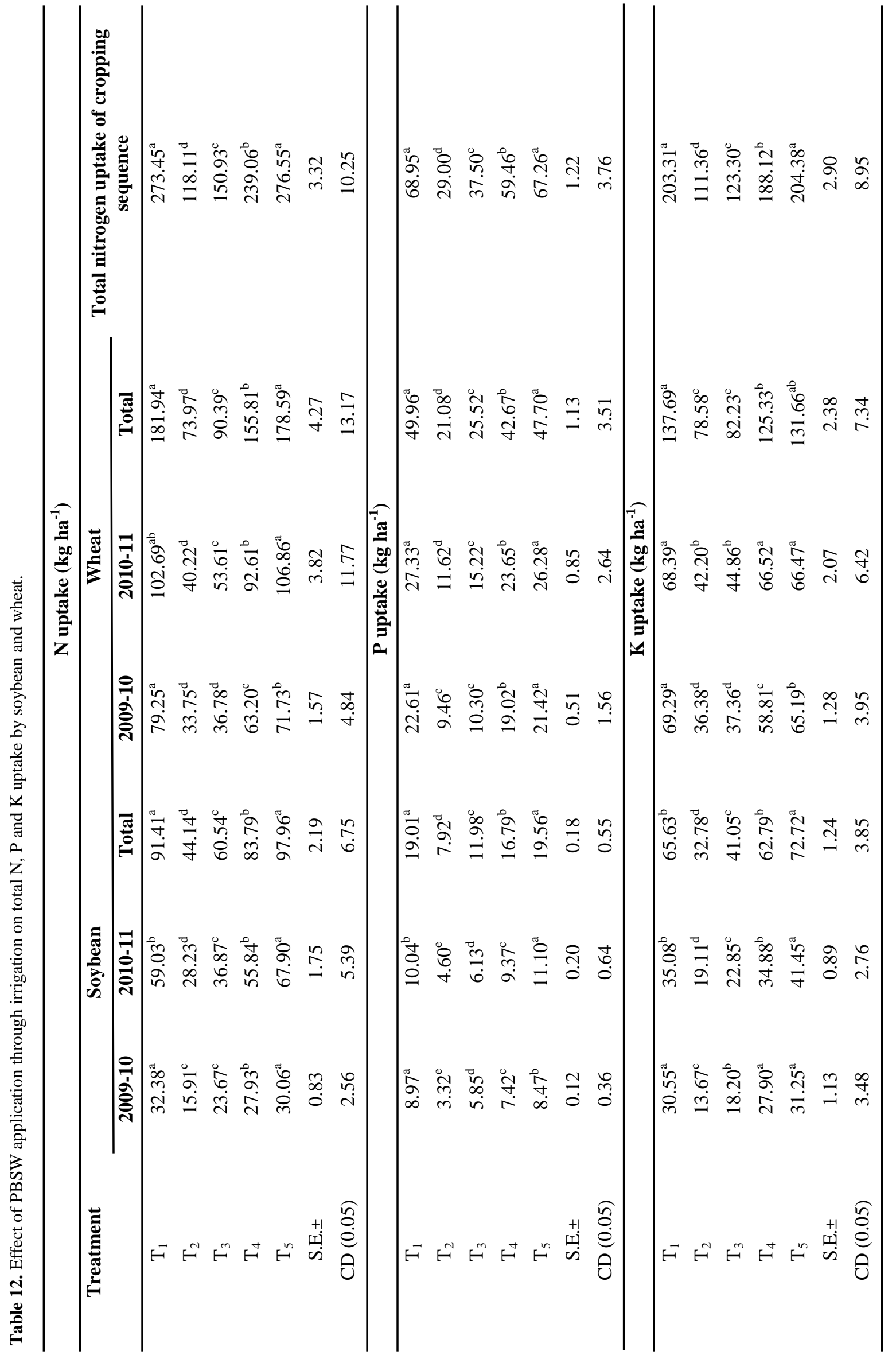


Table 13. Effect of PBSW application through irrigation on grain and straw yield of soybean and wheat.

\begin{tabular}{|c|c|c|c|c|c|c|}
\hline \multirow[b]{2}{*}{ Treatment } & \multicolumn{3}{|c|}{ Soybean grain yield $\left(q\right.$ ha $\left.^{-1}\right)$} & \multicolumn{3}{|c|}{ Soybean straw yield $\left(q\right.$ ha $\left.^{-1}\right)$} \\
\hline & 2009-10 & 2010-11 & $\begin{array}{l}\text { Pooled } \\
\text { mean }\end{array}$ & 2009-10 & $2010-11$ & $\begin{array}{c}\text { Pooled } \\
\text { mean }\end{array}$ \\
\hline$\overline{\mathrm{T}_{1}}$ & $3.83^{\mathrm{a}}$ & $8.02^{\mathrm{b}}$ & 5.93 & $15.02^{\mathrm{a}}$ & $19.94^{\mathrm{a}}$ & 17.48 \\
\hline $\mathrm{T}_{2}$ & $1.98^{\mathrm{c}}$ & $4.39^{\mathrm{d}}$ & 3.19 & $6.93^{\mathrm{b}}$ & $10.50^{\mathrm{b}}$ & 8.72 \\
\hline $\mathrm{T}_{3}$ & $2.35^{\mathrm{c}}$ & $5.73^{c}$ & 4.04 & $13.80^{\mathrm{a}}$ & $12.14^{\mathrm{b}}$ & 12.97 \\
\hline $\mathrm{T}_{4}$ & $3.03^{\mathrm{b}}$ & $7.99^{\mathrm{b}}$ & 5.51 & $13.42^{\mathrm{a}}$ & $17.57^{\mathrm{a}}$ & 15.50 \\
\hline $\mathrm{T}_{5}$ & $3.44^{\mathrm{ab}}$ & $9.46^{\mathrm{a}}$ & 6.45 & $15.45^{\mathrm{a}}$ & $20.39^{\mathrm{a}}$ & 17.92 \\
\hline S.E. \pm & 0.19 & 0.35 & 0.40 & 1.23 & 0.84 & 1.13 \\
\hline \multirow[t]{2}{*}{$\mathrm{CD}(0.05)$} & 0.59 & 1.08 & NS & 3.81 & 2.59 & NS \\
\hline & \multicolumn{3}{|c|}{ Wheat grain yield $\left(q\right.$ ha $\left.^{-1}\right)$} & \multicolumn{3}{|c|}{ Wheat straw yield $\left(q\right.$ ha $\left.^{-1}\right)$} \\
\hline$\overline{\mathrm{T}_{1}}$ & $33.19^{\mathrm{a}}$ & $40.64^{\mathrm{a}}$ & $36.92^{\mathrm{a}}$ & $43.82^{\mathrm{a}}$ & $56.62^{\mathrm{a}}$ & $50.22^{\mathrm{a}}$ \\
\hline $\mathrm{T}_{2}$ & $14.64^{\mathrm{c}}$ & $19.92^{c}$ & $17.28^{\mathrm{d}}$ & $22.14^{\mathrm{c}}$ & $35.45^{\mathrm{b}}$ & $28.80^{\mathrm{b}}$ \\
\hline $\mathrm{T}_{3}$ & $15.84^{\mathrm{c}}$ & $25.70^{c}$ & $20.77^{\mathrm{c}}$ & $22.87^{\mathrm{c}}$ & $37.15^{\mathrm{b}}$ & $30.01^{\mathrm{b}}$ \\
\hline $\mathrm{T}_{4}$ & $27.80^{\mathrm{b}}$ & $34.47^{\mathrm{b}}$ & $31.14^{\mathrm{b}}$ & $33.47^{\mathrm{b}}$ & $55.23^{\mathrm{a}}$ & $44.35^{\mathrm{a}}$ \\
\hline $\mathrm{T}_{5}$ & $29.55^{\mathrm{b}}$ & $37.61^{\mathrm{ab}}$ & $33.58^{\mathrm{b}}$ & $40.96^{\mathrm{a}}$ & $57.35^{\mathrm{a}}$ & $49.16^{\mathrm{a}}$ \\
\hline S.E. \pm & 1.17 & 1.98 & 1.01 & 2.01 & 2.63 & 2.23 \\
\hline $\mathrm{CD}(0.05)$ & 3.60 & 6.11 & 3.12 & 6.20 & 8.12 & 6.71 \\
\hline
\end{tabular}

through chemical fertilizers) was at par with $\mathrm{T}_{1}$ and $\mathrm{T}_{4}$ (3.03 $\left.\mathrm{q} \mathrm{ha}^{-1}\right)$ and the $\mathrm{T}_{2}\left(1.98 \mathrm{q} \mathrm{ha}^{-1}\right)$ treatment showed lowest grain yield of soybean during the year 2009-10, which was at par with $\mathrm{T}_{3}\left(2.35 \mathrm{q} \mathrm{ha}^{-1}\right)$. During 2010-11, the treatment $\mathrm{T}_{5}\left(9.46 \mathrm{q} \mathrm{ha}^{-1}\right)$ had given significantly highest yield of soybean grain, next to that $T_{1}(8.02 \mathrm{q}$ $\mathrm{ha}^{-1}$ ) yielded more which was statistically at par with $\mathrm{T}_{4}\left(7.99 \mathrm{q} \mathrm{ha}^{-1}\right)$. The treatment $\mathrm{T}_{2}\left(4.39 \mathrm{q} \mathrm{ha}^{-1}\right)$ significantly yielded lowest soybean grain during 2010-11. The statistically differences in pooled grain yield of soybean was non significant (Table 13). However, the similar trend of straw yield of soybean was observed as per grain yield. The RD-NPK was at par with $25 \% \mathrm{RD}$ of $\mathrm{N}$ through PBSW + remaining $\mathrm{N}$ and $\mathrm{P}$ - chemical fertilizers for grain yield of soybean during the year 2009-10. It clearly indicated that $25 \% \mathrm{~N}$ fertilizer could be saved by application of PBSW. This might be due to mineralization of organic matter of PBSW and during the mineralization process more availability of nutrients including micronutrients to soybean. Bhosale et al., (2009) reported that the grain and straw yields of soybean were significantly increased over control due to application of various levels of PBSW. The grain yield of soybean at all the levels of PBSW was found significantly superior over control. However, due to uncertainty in rains during kharif, PBSW application through irrigation to soybean can become questionable and hence cannot be recommended.

Grain and straw yield of wheat: The significantly highest pooled grain yield of wheat was recorded in treatment $\mathrm{T}_{1}\left(36.92 \mathrm{q} \mathrm{ha}{ }^{-1}\right)$. Among the PBSW treatments, the highest pooled grain yield of wheat
(33.58 $\mathrm{q} \mathrm{ha}^{-1}$ ) was recorded in treatment $\mathrm{T}_{5}$ and it was at par with $\mathrm{T}_{4}\left(31.14 \mathrm{q} \mathrm{ha}^{-1}\right)$. The lowest grain yield of wheat was obtained in treatment $\mathrm{T}_{2}(100 \% \mathrm{~N}-\mathrm{PBSW}$ + without $\mathrm{P}$ chemical fertilizer) during both the years of experimentation and in pooled means (14.64, 19.92 and $17.28 \mathrm{q} \mathrm{ha}^{-1}$, respectively). The similar trend was observed in straw yield of wheat (Table 13). The increasing grain and straw yield of wheat in 25 and $50 \%$ RD of $\mathrm{N}$ through PBSW and remaining $\mathrm{N}$ and $\mathrm{P}$ through chemical fertilizers treatments was undergone speedy decomposition due to high amount of chemical $\mathrm{N}$ through fertilizers, which was helpful for increasing soil available nitrogen rather than immobilization as seen in $100 \% \mathrm{~N}$-PBSW treatments. The salt load added through 25 or $50 \% \mathrm{~N}-\mathrm{PBSW}$ treatments was also low as compare to $100 \% \mathrm{~N}$-PBSW, which was tolerated by the wheat, due to its well known tolerance nature against salt (Maas and Hoffman, 1977). The other beneficial aspects of PBSW, as it contains micronutrients, plant growth harmones were also helpful for wheat growth at lower salt concentration level (Zalawadia et al., 1997 and Rajukkannu and Manickam, 1997).

Effect of PBSW irrigation on economics of soybean and wheat: The gross returns, net returns and $\mathrm{B}$ : $\mathrm{C}$ ratio of soybean and wheat was highest in treatment $T_{1}$ (Rs. $59969 \mathrm{ha}^{-1}$, Rs. $18540 \mathrm{ha}^{-1}$ and 1.44) in the year 2009-10. During the year 2010-11, the highest gross returns and net returns of soybean and wheat was recorded in treatment $\mathrm{T}_{1}$ (Rs. $76433 \mathrm{ha}^{-1}$ and Rs. 35579 $\mathrm{ha}^{-1}$ ) and $\mathrm{B}$ : C ratio in treatment $\mathrm{T}_{5}$ (1.96). The lowest mean of gross returns, net returns and $\mathrm{B}$ : $\mathrm{C}$ ratio of 
soybean and wheat was recorded in treatment $T_{2}$ in both the years of experimentation. The highest mean of $\mathrm{B}$ : $\mathrm{C}$ ratio of soybean and wheat was observed in treatment $T_{5}$ and followed by $T_{1}$. This might be due to higher grain yield of soybean and wheat crop was obtained in these treatments as compared to other treatments. Balasubramaniam et al. (2013) reported that the $\mathrm{B}$ : $\mathrm{C}$ ratio of 1.82 was recorded by the addition of treated sugarcane distillery effluent @ 40,000 1 ha ${ }^{-1}$ with 100 per cent NPK which was on par with the application of treated sugarcane distillery effluent @ 40,0001 ha $^{-1}$ with 75 per cent NPK.

\section{Conclusion}

Looking to the high BOD, COD, high salt load of PBSW and soil properties, it can be concluded that the $25 \%$ recommended dose of $\mathrm{N}$ through PBSW application through irrigation and remaining $\mathrm{N}$ and $\mathrm{P}$ through chemical fertilizers to soybean and wheat crop was improvement in physical, chemical and microbial soil properties as compared to RD-NPK at all three soil depths. The $25 \%$ N-recommended dose can be replaced by PBSW for soybean and wheat crop in sequence without disturbing soils by salt load. The PBSW application through irrigation in two equal splits at $2^{\text {nd }}$ and $3^{\text {rd }}$ irrigation for soybean and three equal splits at $3^{\text {rd }}, 4^{\text {th }}$ and $5^{\text {th }}$ irrigation for wheat is recommended. The remaining recommended $\mathrm{N}$ and $\mathrm{P}$ dose should be supplied through chemical fertilizers. As the PBSW contain high amount of $\mathrm{K}$, potassium fertilizers should not be added separately.

\section{REFERENCES}

Allison, L.E. and Moodier, C.D. (1965). Carbonate. In: Methods of soil analysis Part II, pp.1379-1396. Am. Soc. Agron. Inc. Madison, Wisconsin, USA.

Balasubramaniam, P., Angelin Silviya, R., Nagarajan, K. and Tajuddin A. (2013). Effect of graded levels of treated sugarcane distillery effluent with soil test based NPK on yield and nutrient uptake of rice (Oryza sativa L.) in sandy clay loam soil. International Journal of Chemical Environment \& Biological Science, 1:380382.

Bhosale, R.S., Pharande, A.L. and Patil, S.R. (2009). Effect of post biomethanated spentwash on potassium behaviour, soil properties, nutrient uptake and yield of soybean in a Inceptisol. In: State level seminar on soil management for food security, 98. Rahuri, India: Mahatma Phule Agricultural University.

Blake, G.R. and Hartge, K.H. (1986). Bulk density. In : Methods of Analysis part I,Physical and mineralogical methods, Second edition, ed. A. Klute, pp. 364-367. Am. Soc. Agron. Inc. Madison, Wisconsin. USA.

Chapman, H.D. and Pratt, P.F.(1961). Methods of analysis for soil, plant and water. pp. 309. Div. Agril. Sci. California Univ., USA.

Deshpande, A.N., Kamble, B.M. Shinde, R.B. and Gore, S. B. (2012). Effect of primary treated biomethanated spentwash on soil properties and yield of sunflower (Helianthus annuus L.) on sodic soil. Communications in Soil Science and Plant Analysis, 43: 730-743.

Deshpande, A.N., Palwe, C.R. and Bagwan, I.R. (2009).Effect of application of post biomethanated spentwash on soil and water properties, nutrient uptake and yield of rainfed pearlmillet in Maharashtra. In: State level seminar on soil management for food security, 91. Rahuri, India: Mahatma Phule Agricultural University.

Deshpande, A.N.,.Palwe, C.R and Ware,R.V. (2011). Residual effect of post biomethanated spent wash on soil properties and yield of chickpea in pearl milletchickpea sequence. In State level seminar on potassium for better production and higher quality of crops 78.Rahuri, India: Mahatma Phule Agricultural University.

Halvorson, H.O. and Ziegler, N.R.(1993).Application of statistics of problems in bacteriology. I.A. means of determining bacterial population by the dilution method. Journal of Bacteriology, 25:101-121.

Hati, K.M., Biswas, A.K.. Bandopadhyay, K.K. and Mishra, A.K. (2004). Effect of post methanation effluent on soil physical properties under a soybean-wheat system in a Vertisol. Journal of the Plant Nutrition and Soil Science, 166: 345-347.

Jackson, M.L. (1973). Soil Chemical Analysis. New Delhi : Prentice Hall of India Pvt. Ltd.

Joshi, H.C., Kalra, N., Chaudhary, A. and Deb, D.L.(1994). Environmental issues related with use of distillery effluents in Agriculture in India. Asia Pacific Journal of Environment Development, 2: 92-103.

Kalaiselvi, P. and Mahimairaja, S.(2010). Effect of spentwash application on nitrogen dynamics in soil. International Journal of Environment Science Development, 1: 184-189.

Kayalvizhi, C., Gopal, M. Subhash, C.B. and Siavanandham, M. (2001). Recycling of distillery effluent in agriculture and effect on soil properties and sugarcane yield. New Delhi: 63rd Annual Convention of Sugar Technologist Association of India. pp :153.

Klute, A. and Dirksen, C. (1986). Hydraulic conductivity and diffusivity, laboratory methods. In : Methods of Soil Analysis. Part I, ed. A.Klute, pp. 687-732. Agron. Monograph No. 9.

Knudsen, D., Peterson, G.A. and Pratt, P.F.(1982). Lithium, sodium and potassium. In: Methods of Soil Analysis Part 2. Chemical and microbiological properties second edition. ed. A. L. Page, R.H. Miller and D.R. Keeney, pp. 225-246. Agron. Monograph No.9, Am. Soc. of Agron. Inc., Soil Sci. Soc. Am. Inc., Madison, Wisconsin, USA.

Maas, E. V. and Hoffman, G. I. (1977). Crop salt tolerance current assessment. Journal of Irrigation and Drainage, 103: 115-134.

Mallika, R., Prabhakaran, J. and Lakshmanan, A. (2003). Influence of distillery spentwash application on the microbial population dynamics and enzyme activity of maize soil. Madras Agricultural Journal,90: 589-595.

Manohar Rao. (1983). Production of methane gas from stillage on commercial scale in India. Indian Sugar, 32:873-880.

Murugaragavan, R. (2002). Distillery spent wash on crop production dry land soils. MSc Thesis, Tamil Nadu Agricultural University, Coimbatore, India.

Nelson, D.W. and Sommers, L.E. (1982). Total carbon, Organic carbon and Organic matter. In: Methods of Soil 
Analysis Part 2. Chemical and microbiological properties second edition. ed. A.L. Page, R.H. Miller and D.R. Keeney, pp. 539-579. Agron. Monograph No.9, Am. Soc. of Agron. Inc., Soil Sci. Soc. Am. Inc., Madison, Wisconsin, USA.

Olsen, S.R., Coles, C.V., Watanabe, F.S. and Dean, L.N. (1954). Estimation of available phosphorus in soils by extraction with sodium bicarbonate. USDA Circular 939.

Palemio, M. and Rhoades, J.D. (1977). Determining cation exchange capacity: A new procedure for calcareous and gypsiferrous soil. Soil Science Society of America Journal,41:524-528.

Panse, V.G. and Sukhatme, P.V. (1985). Statistical Methods for Agricultural Workers, ICAR, New Delhi.

Parkinson, J.A., and Allen, S.E.(1975). A wet oxidation procedure suitable for the determination of nitrogen and other mineral nutrients in biological material. Communications in Soil Science and Plant Analysis, 6: 7-11.

Rajukkannu, K. and Manickam, T.S.(1997). Use of distillery and sugar industry waste in agriculture. In :Proceedings of the Sixth National Symposium on Environment, 286- 290, Coimbatore, India: Tamil Nadu Agricultural University.

Richards, L.A. (1954). Diagnosis and improvement of saline and alkali soils. US Salinity Lab., US Department of
Agriculture Handbook 60. California, USA.

Saliha, B.B. (2003). Eco-friendly utilization of distillery spentwash for improving agricultural productivity in dryland and high $\mathrm{pH}$ soils of Theni district. $\mathrm{PhD}$ Thesis, Tamil Nadu Agricultural University, Madurai, India.

Subbiah, B.V. and Asija, G.L. (1956). A rapid procedure for the estimation of available nitrogen in soils. Current Science, 25: 259-260.

Sukanya, T.S. and Meli, S.S.(2004). Response of wheat to graded dilution of liquid distillery effluent (spent wash) on plant nutrient contents, nutrient uptake, crop yield and residual soil fertility. Karnataka Journal of Agricultural Science, 17(3):417-420.

Zalawadia, N.M. and Raman, S. (1994). Effect of distillery waste water with graded fertilizer levels on sorghum yield and soil properties. Journal of the Indian Society of Soil Science, 42: 575-579.

Zalawadia, N.M.,Raman, S. and Patil, R.G. (1997). Influence of diluted spentwash of sugar industries application on yield and nutrient uptake by sugarcane and change in soil properties. Journal of the Indian Society of Soil Science, 45: 767-769. 